Marcelina Krupa-Małkiewicz*, Beata Smolik**, Dominik Ostojski*, Maja Sędzik**, Justyna Pelc**

\title{
Effect of ascorbic acid on morphological and biochemical parameters in tomato seedling exposure to salt stress
}

\author{
Wpływ kwasu askorbinowego na cechy morfologiczne \\ i parametry biochemiczne siewek pomidora \\ poddanego działaniu stresu solnego
}

* Dr inż. Marcelina Krupa-Małkiewicz, Dominik Ostojski, Department of Plant Genetics, Breeding and Biotechnology, West Pomeranian University of Technology in Szczecin, Stowackiego 17 St., 71-434 Szczecin e-mail:mkrupa@zut.edu.pl
** Dr hab. Beata Smolik, mgr Maja Sędzik, mgr Justyna Pelc, Department of Plant Physiology and Biochemistry, Faculty of Environmental Management and Agriculture, West Pomeranian University of Technology in Szczecin, Słowackiego 17 St., 71-434 Szczecin

Keywords: ascorbic acid, salinity, tomato, proline, malondialdehyde

Słowa kluczowe: kwas askorbinowy, zasolenie, pomidor, prolina, dialdehyd malonowy

\section{Abstract}

The aim of this study is to determine the effect of both $\mathrm{NaCl}$ and $\mathrm{KCl}$ alone and in comparison to AsA on the morphological and some biochemical parameters of Oxheart and Vilma cultivars of tomato under laboratory and field conditions. A combination of salt applied in the laboratory experiment caused a significant effect on seed germination and root and shoot length and a significant reduction of $\mathrm{Chl} a, \mathrm{Chl} b$ and Car contents in 14-dayold tomato seedlings. However, seedlings of cultivar Vilma were characterised by higher tolerance to applied salt stress.

$\mathrm{NaCl}$ caused a significant decrease in $\mathrm{Chl} a, \mathrm{Chl} b$ and Car, and an increase in Pro and MDA content in the leaves of Vilma cultivar under field conditions. Besides, tomato plants cv. Vilma treated with $\mathrm{NaCl}$ alone or $\mathrm{NaCl}$ with ascorbic acid developed longer roots, from 48 to $73 \%$, compared to the control.

\section{Streszczenie}

Celem pracy było określenie wpływu soli $\mathrm{NaCl}$ i $\mathrm{KCl}$ osobno oraz w połączeniu z kwasem askorbinowym na cechy morfologiczne i niektóre parametry biochemiczne siewek dwóch odmian pomidora: Oxheart i Vilma w warunkach laboratoryjnych. Zastosowanie kombinacji roztworów soli miało istotny wpływ na zdolność kiełkowania nasion, długość korzeni i pędów, a także redukowało zawartość Chl a, Chl b i Car w 14-dniowych siewkach pomidora. Ponadto, odmiana Vilma charakteryzowała się zwiększoną tolerancją na działanie stresu solnego w porównaniu do odmiany Oxheart.

W warunkach polowych, zastosowany roztwór soli $\mathrm{NaCl}$ obniżał stężenie $\mathrm{Chl} a, \mathrm{Chl} b$ i Car, jednocześnie podwyższając parametry stresu oksydacyjnego - proliny i dialdehydu malonowego w liściach odmiany Vilma. Ponadto, rośliny odmiany Vilma traktowane roztworem soli $\mathrm{NaCl}$ osobno lub $\mathrm{w}$ połączeniu z kwasem askorbinowych wykształciły o 48 - 73\% dłuższe korzenie w porównaniu do kontroli.

() IOŚ-PIB

\section{INTRODUCTION}

Salinity is one of the worldwide environmental and agricultural constraints to crop production. Nearly $20 \%$ of the cultivated land is affected by salinity [Sajid et al., 2009; Bybordi 2012; Saeidi-Sar et al. 2013]. Abiotic stresses adversely affect plant cultivation by hampering the uptake of water from the soil land simultaneously reducing their normal growth [Cuartero et al. 2006; Smolik et al. 2011]. To overcome water deficit, plants have developed mechanisms of physiological adaptation, such as development of a root system to acquire water or accumulation of osmoprotectants. One such osmoprotectant is proline, and its accumulation is widely observed in various organisms under salt stress [Demir and Kocaçalişkan 2002; Rahnama and Ebrahimzadeh 2004; Yamada et al. 2005; Smolik et al. 2011]. Under osmotic stress conditions, prolines maintain osmoregulation, act as a protector of macromolecules such as proteins and cell membranes, but its presence is primarily indicated as a stress-related signal.
Thus, changes in the content of proline may be used to evaluate the differences in the reaction of plants in experiments with the controlled influence of one stressor [Demir and Kocaçalişkan 2002; Rahnama and Ebrahimzadeh 2004]. In spite of many studies in plants, physiological role of proline under salt stress is still uncertain.

The conventional plant breeding strategy for overcoming the negative effects of salinity has still limited success. An efficient technique to alleviate salinity stress in plants is application of non-enzymatic antioxidants, such as ascorbic acid (AsA) [Bybordi 2012; Agami 2014]. AsA, as water-soluble vitamins, is one of the important antioxidant in plants that accumulates in different parts of plant. Generally, its concentration is higher in leaves than in other plants part. AsA is regarded as one of the most effective compounds able to ameliorate abiotic stresses [Agami 2014]. AsA not only acts as an antioxidant but also as an 
activation of some of the enzymatic reactions, induction of stressresponsive proteins synthesis and the production of various chemical defense compounds [Khan et al. 2011; Agami 2014]. It has been used to counteract the adverse effects of salinity in many crop plants [Sajid and Aftab 2009; Bybordi 2012; SaeidiSar et al. 2013; Agami 2014]

According to many authors [Saeidi-Sar et al. 2013; Smolik et al. 2013] malondialdehyde (MDA) is also good indicator of the level of stress in plants. MDA as a product of lipid peroxidation is accumulated in tissues when plants are exposed to salinity stress.

Proper assessment of the response to salinity and selection of tolerant genotypes from cultivated plants, including tomato, depends on the availability of verified assessment methods and access to diverse genetic resource, that is, source of tolerance genes and wild tolerant genotypes [Aslan et al. 2011; KrupaMałkiewicz et al. 2014]. Wild tomatoes exhibit wide differences in salt tolerance and that is why are good materials to improve the resistance of cultivated tomatoes to unfavourable environmental conditions [Rzepka-Plevneš et al 2007]. One of the methods that can significantly shorten a breeding cycle and test a greater number of plants in laboratory stress conditions is in vitro culture. Additionally, it is also an effective method for the selection for abiotic stress tolerance. According to some authors [RzepkaPlevneš et al. 2008; Goel et al., 2010], the tolerance to abiotic stress at seedling stage is positively correlated with the tolerance to abiotic stress in mature plants.

The major objective of this study is to investigate the effects of AsA on the number of physiological aspects of tomato plants under saline condition in vitro and in vivo.

\section{MATERIALS AND METHODS}

Pan test Seeds of two tomato (Lycopersicon esculentum) cultivars: Oxheart and Vilma were surface-sterilised with $70 \%$ $(v / v)$ ethanol solution for 30 seconds and then thoroughly rinsed with sterile water. After the preliminary disinfection, the explants were soaked for 15 minutes in $10 \%(\mathrm{v} / \mathrm{v})$ solution of sodium hypochlorite $(\mathrm{NaOCl})$, after rinsing three times in sterile water. Next, seeds were placed in petri dishes lined with filter paper and moistened with $15.0 \mathrm{dm}^{3}$ of salt solution. To obtain a salinity effect, eight combinations of two salt solutions $(\mathrm{NaCl}$ and $\mathrm{KCl}$ ) were used: $100 \mathrm{mM} \mathrm{NaCl}, 100 \mathrm{mM} \mathrm{NaCl}+1 \mathrm{M} \mathrm{AsA}$, $200 \mathrm{mM} \mathrm{NaCl}, 200 \mathrm{mM} \mathrm{NaCl}+1 \mathrm{M} \mathrm{AsA}, 100 \mathrm{mM} \mathrm{KCl}, 100$ $\mathrm{mM} \mathrm{KCl}+1 \mathrm{M} \mathrm{AsA}, 200 \mathrm{mM} \mathrm{KCl}, 200 \mathrm{mM} \mathrm{KCl}+1 \mathrm{M} \mathrm{AsA}$, with a $\mathrm{pH}$ of 6.0. Sterile water was used as the control. Twenty seeds were used per treatment, including control, for each cultivar. The experiments were repeated three times. The petri dishes with the seeds were stored in a growth chamber at a constant temperature of $25^{\circ} \mathrm{C}$ in white light $\left(40 \mu \mathrm{mol} \cdot \mathrm{m}^{-2} \cdot \mathrm{s}^{-1}\right)$ for 16 hours. After 14 days, plants were removed and washed with deionised distilled water. Biometric measurements were performed, in which the following parameters were determined: the number of germinating seeds, seedling's height $(\mathrm{cm})$ and the length of roots $(\mathrm{cm})$, and Chlorophyll $a$, Chlorophyll $b$ and Carotenoid concentrations $\left(\mathrm{mg} \cdot \mathrm{g}^{-1} \mathrm{fw}\right)$ in tomato seedlings.
Field test Seeds of cultivar Vilma were disinfected with 10\% solution of $\mathrm{NaOCl}$ for 15 minutes. Then, they were washed three times with sterile water and seeded on pots (diameter $10 \mathrm{~cm}$ ) and filled with soil. Pots were then moved to a heated greenhouse and placed on cultivation tables. A dose of $10 \mathrm{~g} \cdot \mathrm{m}^{-2}$ of Azofoska fertiliser was applied as top dressing once during the vegetation season. After the development of the root system of a plant (about 3 weeks after planting of seeds), watering using $\mathrm{NaCl}$ solution in four combinations was initiated: $3.0 \mathrm{~g} \cdot \mathrm{dm}^{-3} \mathrm{NaCl}$, $3.0 \mathrm{~g} \cdot \mathrm{dm}^{-3} \mathrm{NaCl}+1 \mathrm{M} \mathrm{AsA}, 6.0 \mathrm{~g} \cdot \mathrm{dm}^{-3} \mathrm{NaCl}, 6.0 \mathrm{~g} \cdot \mathrm{dm}^{-3} \mathrm{NaCl}+$ $1 \mathrm{M}$ AsA. Salination was carried out for 6 weeks, once a week, applying $150 \mathrm{dm}^{3}$ of stock solution per pot. The control group involved plants were watered with distilled water at the same doses. The experiment was established in three replications, with 10 plants in a replication. At the end of the vegetation season, the percentage of plants that survived was established, length of the shoots and roots $(\mathrm{cm})$, number of shoots and roots and number of buds, the levels of $\mathrm{Chl} a, \mathrm{Chl} b$ and Car $\left(\mathrm{mg} \cdot \mathrm{g}^{-1} \mathrm{fw}\right)$, concentrations of proline $\left(\mu \mathrm{mol} \cdot \mathrm{g}^{-1} \mathrm{fm}\right)$ and MDA $\left(\mathrm{nmol} \cdot \mathrm{g}^{-1} \mathrm{fm}\right)$ in leaves were measured.

Determination of proline and MDA content The concentration of free proline in each tomato genotype has been measured three times. The proline accumulation was determined according to Bates [1973]. Content of the MDA in plant tissue was determined by the method described by Sudhakar et al. [2001].

Determination of pigments The levels of Chlorophyll $a, b$ and carotenoid (Car) were measured in $80 \%(\mathrm{v} / \mathrm{v})$ acetone extracts according to Arnon et al. [1956] in modification to Lichtenthaler and Wellburn [1983]. The concentration of $\mathrm{Chl} a$ and $\mathrm{Chl} b$ were calculated from equations derived by Hendry and Grime [1993]

Chl $a\left(m g \cdot g^{-1} f w\right)=\left[\left(12.7 A_{663}-2.69 A_{645}\right) / 1000 \times f w\right] \times V$

Chl $b\left(\mathrm{mg} \cdot \mathrm{g}^{-1} \mathrm{fw}\right)=\left[\left(22.9 \mathrm{~A}_{645}-4.68 \mathrm{~A}_{663}\right) / 1000 \times \mathrm{fw}\right] \times \mathrm{V}$

Car content was determined by the equation of Price and Henry [1991]

$\operatorname{Car}\left(m g \cdot g^{-1} f w\right)=\left[\left(A_{480}+0.114 A_{663}\right)-\left(0.638 A_{663}\right) \times V / 112.5 \times f w\right]$

where $\mathrm{V}$ is volume of the sample $(\mathrm{mL}), \mathrm{A}$ is absorbance and $\mathrm{fw}$ is fresh weight $(\mathrm{g})$.

Statistical analysis The significance of differences was determined by means of variance analysis and Tukey's test, at the level of significance of $\alpha=0.05$. Homogenous groups between analysed combinations were labelled with successive letters of alphabet.

\section{RESULTS AND DISSCUSION}

Salinity caused significant inhibition in plant growth and metabolism [Bybordi 2012; Saeidi-Sar et al. 2013; Smolik et al. 2013]. The results showed that salt stress affects differently in early growth stages of plant. The growth characteristics of tomato seedlings under salinity stress were effectively improved with AsA 
supplement. This treatment can reduce the deleterious effects of salt stress. In addition, AsA is a co-factor for prolyl-hydroxylase that post-translationally hydroxylates proline residues in cell wall hydroxyproline-rich glycoproteins required for cell division and expansion [Smirnoff and Wheeler 2000; Saeidi-Sar et al. 2013]. Tomato varieties examined differed significantly with regard to percentage of germinated seeds, shoot and root length of 14 days seedlings tolerant to salt under laboratory conditions (Table 1). Oxheart cultivar proved to be most sensitive when treated with $\mathrm{NaCl}$ and $\mathrm{KCl}$. Seeds did not germinate above $100 \mathrm{mM} \mathrm{NaCl}$ and $100 \mathrm{mM} \mathrm{KCl}$. The highest germination of seeds (82.5\%) occurred in the control medium without the addition of salt (Table 1). In the case of Vilma cultivar, $\mathrm{NaCl}$ and $\mathrm{KCl}$ at a concentration of $200 \mathrm{mM}$ inhibited seed germination. Application of AsA, however, resulted not only in seed germination but also increased shoot/ root growth cvs. Oxheart and Vilma (Table 1). In each experiment combination, when the media was supplemented with vitamin $\mathrm{C}$, the seedlings of the Vilma cultivar were higher and exhibited longer roots compared to seedlings from a medium without the addition of vitamin C. According to many authors [Cuartero and Fernandez-Muñoz 1999; Smolik et al. 2011; Krupa-Małkiewicz et al. 2014], young seedlings are most sensitive to the effect of salt solution. Results obtained in this study were consistent with the results obtained by Jones [1986], who showed that an increase in salt concentration up to $100 \mathrm{mM}$ in the medium has a distinctly inhibitory effect on the germination ability of tomato seeds.
Salinity stress led to a significant decrease in $\mathrm{Chl} a, \mathrm{Chl} b$ and Car contents (Table 1). For both Oxheart and Vilma cultivars, the values of the biochemical parameters discussed were significantly lower compared to the control (14.05, 6.12, $5.85 \mathrm{mg} \cdot \mathrm{g}^{-1} \mathrm{fm}$, respectively). However, an evidently positive impact on the biochemical properties tested in Vilma cultivar was observed after treatment with $\mathrm{NaCl}$ or $\mathrm{KCl}$ solutions in combination with vitamin C. Similar results were obtained by Saeidi-Sar et al. [2013] for the common bean, where plants treated with AsA and $\mathrm{GA}_{3}$ were less affected by a decreased content of $\mathrm{Chl} a, \mathrm{Chl} b$ and Car.

Based on the laboratory experiment conducted, the Vilma cultivar was selected for the field experiment. The ability of seeds to germinate under field conditions was $100 \%$. The addition of $\mathrm{NaCl}$ salt solution to the medium, regardless of concentration, negatively affected such characteristics as plant height, number of shoots, roots and buds per plant (Table 2). Length of the roots constituted an exception, where Vilma tomato plants from each combination of experiment developed roots longer by $48-73 \%$ compared to the control. According to Saeidi-Sar et al. [2013] and Bybordi [2012], the beneficial effect of AsA on plant growth may be attributed to the fact that AsA is involved in the regulation of root elongation, cell vacuolation and cell expansion. The concentration of chlorophylls and carotenoids in leaves of cv. Vilma were significantly decreased by salt stress, especially where concentration of $6 \mathrm{~g} \cdot \mathrm{dm}^{-3} \mathrm{NaCl}$ were used (Table 3). According to many authors [Ashraf et al 2002; Bybordi 2012;

Table 1. Seed germination and seedling growth and $\mathrm{Chl} a, \mathrm{Chl} b$, Car concentrations of tomato cvs. Oxheart and Vilma at different salt treatment

\begin{tabular}{|c|c|c|c|c|c|c|c|c|c|c|c|}
\hline \multirow{3}{*}{ Treatment } & \multirow{3}{*}{$\begin{array}{c}\text { Germina- } \\
\text { tion } \\
(\%)\end{array}$} & \multirow{3}{*}{\multicolumn{2}{|c|}{$\begin{array}{l}\text { Root length } \\
\text { (cm) }\end{array}$}} & \multirow{3}{*}{\multicolumn{2}{|c|}{$\begin{array}{l}\text { Shoot length } \\
\text { (cm) }\end{array}$}} & \multicolumn{6}{|c|}{ Pigments contents } \\
\hline & & & & & & \multirow{2}{*}{\multicolumn{2}{|c|}{ Chl a }} & \multirow{2}{*}{\multicolumn{2}{|c|}{$\begin{array}{c}C h l b \\
\left.\mathrm{ng} \cdot \mathrm{g}^{-1} \mathrm{fw}\right)\end{array}$}} & \multirow{2}{*}{\multicolumn{2}{|c|}{ Car }} \\
\hline & & & & & & & & & & & \\
\hline \multicolumn{12}{|c|}{ Oxheart } \\
\hline Control & 82.5 & $13.88 \pm 8.00$ & $a^{*}$ & $15.42 \pm 7.35$ & a & $14.05 \pm 3.12$ & a & $6.12 \pm 0.83$ & a & $5.85 \pm 1.12$ & a \\
\hline $100 \mathrm{mM} \mathrm{NaCl}$ & 0 & 0 & c & 0 & $d$ & 0 & e & 0 & $d$ & 0 & $d$ \\
\hline $100 \mathrm{mM} \mathrm{NaCl}+1 \mathrm{M} \mathrm{AsA}$ & 45 & $10.09 \pm 3.67$ & $a b$ & $10.61 \pm 7.19$ & $a b$ & $6.69 \pm 2.54$ & c & $2,72 \pm 0.74$ & c & $2.85 \pm 1.06$ & c \\
\hline $200 \mathrm{mM} \mathrm{NaCl}$ & 0 & 0 & c & 0 & $d$ & 0 & $\mathrm{e}$ & 0 & d & 0 & $d$ \\
\hline $200 \mathrm{mM} \mathrm{NaCl}+1 \mathrm{M} \mathrm{AsA}$ & 0 & 0 & c & 0 & $d$ & 0 & e & 0 & d & 0 & $d$ \\
\hline $100 \mathrm{mM} \mathrm{KCl}$ & 0 & 0 & c & 0 & $d$ & 0 & e & 0 & d & 0 & $d$ \\
\hline $100 \mathrm{mM} \mathrm{KCL}+1 \mathrm{M} \mathrm{AsA}$ & 67.5 & $9.48 \pm 4.28$ & $a b$ & $12.91 \pm 7.62$ & $a b$ & $9.34 \pm 4.62$ & $b$ & $3.91 \pm 2.63$ & $\mathrm{~b}$ & $3.86 \pm 1.83$ & $\mathrm{~b}$ \\
\hline $200 \mathrm{mM} \mathrm{KCl}$ & 0 & 0 & c & 0 & $d$ & 0 & e & 0 & $d$ & 0 & $d$ \\
\hline $200 \mathrm{mM} \mathrm{KCl}+1 \mathrm{M} \mathrm{AsA}$ & 22.5 & $6.09 \pm 1.99$ & $b$ & $6.64 \pm 8.28$ & bcd & $4.71 \pm 0.1$ & $d$ & $2.64 \pm 0.1$ & c & $2.21 \pm 0.05$ & c \\
\hline \multicolumn{4}{|c|}{4.78} & \multicolumn{2}{|l|}{7.27} & \multicolumn{2}{|l|}{1.87} & \multicolumn{2}{|l|}{0.95} & \multicolumn{2}{|l|}{0.73} \\
\hline \multicolumn{12}{|c|}{ Vilma } \\
\hline Control & 93 & $12.21 \pm 14.91$ & a & $13.48 \pm 3.05$ & a & $15.64 \pm 2.78$ & a & $5.19 \pm 1.78$ & $a$ & $6.61 \pm 1.22$ & a \\
\hline $100 \mathrm{mM} \mathrm{NaCl}$ & 77.5 & $2.09 \pm 1.18$ & $\mathrm{~b}$ & $12.21 \pm 3.28$ & $a b$ & $5.74 \pm 1.54$ & $\mathrm{~b}$ & 2.12 & $\mathrm{bc}$ & $2.38 \pm 0.56$ & c \\
\hline $100 \mathrm{mM} \mathrm{NaCl}+1 \mathrm{M} \mathrm{AsA}$ & 82.5 & $4.48 \pm 1.54$ & $\mathrm{~b}$ & $12.33 \pm 5.35$ & $a b$ & $6.55 \pm 0.88$ & $\mathrm{~b}$ & $2.16 \pm 0.3$ & $\mathrm{bc}$ & $2.96 \pm 0.34$ & b \\
\hline $200 \mathrm{mM} \mathrm{NaCl}$ & 0 & 0 & $b$ & 0 & $d$ & 0 & e & 0 & $\mathrm{e}$ & 0 & $\mathrm{e}$ \\
\hline $200 \mathrm{mM} \mathrm{NaCl}+1 \mathrm{M} \mathrm{AsA}$ & 52.5 & $3.30 \pm 1.65$ & $\mathrm{~b}$ & $6.48 \pm 4.93$ & c & $6.55 \pm 0.22$ & $\mathrm{~b}$ & $2.65 \pm 0.15$ & $\mathrm{~b}$ & $3.04 \pm 0.13$ & b \\
\hline $100 \mathrm{mM} \mathrm{KCl}$ & 40 & $4.45 \pm 2.41$ & $\mathrm{~b}$ & $5.33 \pm 5.14$ & $\mathrm{~cd}$ & $2.33 \pm 1.33$ & $d$ & $0.85 \pm 0.56$ & $d$ & $1.19 \pm 0.51$ & $d$ \\
\hline $100 \mathrm{mM} \mathrm{KCL}+1 \mathrm{M} \mathrm{AsA}$ & 82.5 & $4.58 \pm 2.77$ & $\mathrm{~b}$ & $9.64 \pm 4.54$ & $a b c$ & $4.41 \pm 0.43$ & $\mathrm{c}$ & $1.78 \pm 0.09$ & $\mathrm{c}$ & $2.32 \pm 0.14$ & c \\
\hline 200 mM KCl & 0 & 0 & $\mathrm{~b}$ & 0 & $d$ & 0 & e & 0 & e & 0 & $\mathrm{e}$ \\
\hline $200 \mathrm{mM} \mathrm{KCl}+1 \mathrm{M} \mathrm{AsA}$ & 73 & $4.21 \pm 1.85$ & $b$ & $7.03 \pm 4.14$ & $\mathrm{bc}$ & $2.36 \pm 0.87$ & $d$ & $1.03 \pm 0.46$ & $d$ & $1.24 \pm 0.41$ & $d$ \\
\hline $\operatorname{LSD}_{0.05}$ & & \multicolumn{2}{|l|}{7.47} & \multicolumn{2}{|l|}{5.57} & 0.92 & & \multicolumn{2}{|l|}{0.61} & \multicolumn{2}{|l|}{0.38} \\
\hline
\end{tabular}

"Means in the same column followed by the same letter are not significantly different $(p<0.05$; Least Significant Differences test LSD) Chl a, Chl b, Car: Chlorophyll a, Chlorophyll $b$ and carotenoid 
Table 2. The influence of $\mathrm{NaCl}$ and $\mathrm{KCl}$ salt solution on morphological traits of tomato $\mathrm{cv}$. Vilma under field conditions

\begin{tabular}{|c|c|c|c|c|c|c|c|c|c|c|}
\hline Treatment & \multicolumn{2}{|c|}{$\begin{array}{l}\text { Plant height } \\
{[\mathrm{cm}]}\end{array}$} & \multicolumn{2}{|c|}{$\begin{array}{c}\text { Number of shoots } \\
\text { per plant }\end{array}$} & \multicolumn{2}{|c|}{ Root length [cm] } & \multicolumn{2}{|c|}{ Number of roots } & \multicolumn{2}{|c|}{ Number of buds } \\
\hline Control & $31.33 \pm 4.59$ & $a^{*}$ & $10.50 \pm 1.93$ & a & $7.88 \pm 4.61$ & a & $30.63 \pm 5.97$ & a & $6.34 \pm 3.45$ & a \\
\hline $3 \mathrm{~g} \cdot \mathrm{dm}^{-3} \mathrm{NaCl}$ & $18.50 \pm 3.60$ & $b$ & $8.58 \pm 1.67$ & a & $12.25 \pm 5.28$ & a & $24.63 \pm 4.75$ & $a b$ & $4.50 \pm 3.20$ & $a b$ \\
\hline $3 \mathrm{~g} \cdot \mathrm{dm}^{-3} \mathrm{NaCl}+1 \mathrm{M} \mathrm{AsA}$ & $18.33 \pm 3.57$ & $b$ & $8.33 \pm 1.43$ & a & $13.63 \pm 4.24$ & a & $22.63 \pm 5.70$ & $a b$ & $4.00 \pm 2.86$ & $a b$ \\
\hline $6 \mathrm{~g} \cdot \mathrm{dm}^{-3} \mathrm{NaCl}$ & $15.33 \pm 2.49$ & $\mathrm{~b}$ & $6.83 \pm 1.27$ & a & $13.25 \pm 6.20$ & a & $22.88 \pm 2.58$ & $a b$ & $3.75 \pm 3.14$ & $a b$ \\
\hline $6 \mathrm{~g} \cdot \mathrm{dm}^{-3} \mathrm{NaCl}+1 \mathrm{M} \mathrm{AsA}$ & $14.50 \pm 2.87$ & $\mathrm{~b}$ & $6.17 \pm 1.46$ & a & $11.63 \pm 5.63$ & a & $17.63 \pm 4.17$ & $b$ & $0.84 \pm 1.94$ & $\mathrm{~b}$ \\
\hline $\operatorname{LSD}_{0.05}$ & \multicolumn{2}{|l|}{5.86} & \multicolumn{2}{|l|}{8.38} & \multicolumn{2}{|l|}{8.89} & \multicolumn{2}{|l|}{8.14} & \multicolumn{2}{|l|}{4.96} \\
\hline
\end{tabular}

"Means in the same column followed by the same letter are not significantly different $(p<0.05$; Least Significant Differences test LSD)

Table 3. Concentration of $\mathrm{Chl} a, \mathrm{Chl} b$, Car, MDA and Pro in leaves of tomato cv. Vilma depending on different salt treatment

\begin{tabular}{|c|c|c|c|c|c|c|c|c|c|c|}
\hline Treatment & \multicolumn{2}{|c|}{$\begin{array}{c}\mathrm{Chl} \mathrm{a} \\
{\left[\mathrm{mg} \cdot \mathrm{g}^{-1} \mathrm{fm}\right]}\end{array}$} & \multicolumn{2}{|c|}{$\begin{array}{c}C h / b \\
{\left[\mathrm{mg} \cdot \mathrm{g}^{-1} \mathrm{fm}\right]}\end{array}$} & \multicolumn{2}{|c|}{$\begin{array}{c}\text { Car } \\
{\left[\mathrm{mg} \cdot \mathrm{g}^{-1} \mathrm{fm}\right]}\end{array}$} & \multicolumn{2}{|c|}{$\begin{array}{c}\text { Pro } \\
{\left[\mu \mathrm{mol} \cdot \mathrm{g}^{-1} \mathrm{fm}\right]}\end{array}$} & \multicolumn{2}{|c|}{ 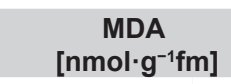 } \\
\hline Control & $60.07 \pm 7.68$ & a & $24.21 \pm 3.06$ & a & $25.26 \pm 3.23$ & a & $10.77 \pm 2.58$ & c & $14.60 \pm 1.25$ & c \\
\hline $3 \mathrm{~g} \cdot \mathrm{dm}^{-3} \mathrm{NaCl}$ & $49.08 \pm 11.34$ & $b$ & $19.60 \pm 4.46$ & $\mathrm{~b}$ & $21.03 \pm 4.86$ & $b$ & $36.08 \pm 15.95$ & $b$ & 22. $42 \pm 6.16$ & $\mathrm{~b}$ \\
\hline $3 \mathrm{~g} \cdot \mathrm{dm}^{-3} \mathrm{NaCl}+1 \mathrm{M}$ AsA & $52.14 \pm 10.13$ & $b$ & $21.1 \pm 4.27$ & $a b$ & $22.74 \pm 4.29$ & $b$ & $34.40 \pm 0.44$ & $b$ & $26.05 \pm 7.18$ & a \\
\hline $6 \mathrm{~g} \cdot \mathrm{dm}^{-3} \mathrm{NaCl}$ & $39.63 \pm 6.85$ & c & $15.24 \pm 2.62$ & c & $16.39 \pm 2.50$ & c & $38.35 \pm 20.36$ & $a b$ & $28.31 \pm 1.94$ & a \\
\hline $6 \mathrm{~g} \cdot \mathrm{dm}^{-3} \mathrm{NaCl}+1 \mathrm{M} \mathrm{AsA}$ & $32.15 \pm 0.64$ & $d$ & $13.37 \pm 0.77$ & c & $14.56 \pm 0.83$ & c & $46.25 \pm 13.93$ & a & $21.85 \pm 4.09$ & $\mathrm{~b}$ \\
\hline $\mathrm{LSD}_{0.05}$ & \multicolumn{2}{|l|}{5.44} & \multicolumn{2}{|l|}{2.19} & \multicolumn{2}{|l|}{2.28} & \multicolumn{2}{|l|}{8.74} & \multicolumn{2}{|l|}{3.23} \\
\hline
\end{tabular}

"Means in the same column followed by the same letter are not significantly different $(p<0.05$; Least Significant Differences test LSD) $C h l a, C h l b$, Car: Chlorophyll a, Chlorophyll $b$ and carotenoid; MDA: malondialdehyde; Pro: proline

Saeidi-Sar et al. 2013], $\mathrm{NaCl}$ caused a significant decrease in chlorophylls and in anthocyanin contents. It is probably due to the inhibitory effect of the accumulated ions of various salts on the biosynthesis of the different chlorophyll fractions. Similarly, the concentration of proline increased with increasing salinity levels (Table 3 ). The contents of proline significantly increased $\left(46.25 \mu \mathrm{mol} \cdot \mathrm{g}^{-1} \mathrm{fm}\right)$ when $6 \mathrm{~g} \cdot \mathrm{dm}^{-3} \mathrm{NaCl}$ with combination of 1 $\mathrm{M}$ AsA were used compared to the control $\left(10.77 \mu \mathrm{mol} \cdot \mathrm{g}^{-1} \mathrm{fm}\right)$. According to Demir and Kocaçalişkan [2002] and Bybordi [2012], high proline concentration has been indicated as tolerance criterion in relation to the mechanism of osmoregulation in several plants.

Salt stress affected statistically significant increase in MDA content (Table 3). Tomato plants treated with $6 \mathrm{~g} \cdot \mathrm{dm}^{-3} \mathrm{NaCl}$ had the highest level of MDA in leaves $\left(28.31 \mathrm{nmol} \cdot \mathrm{g}^{-1} \mathrm{fm}\right)$ than the control or those with other treatment. The application of AsA led to a higher decrease in the leaves MDA content under stress condition. On the other hand, in the presence of $3 \mathrm{~g} \cdot \mathrm{dm}^{-3} \mathrm{NaCl}$, application of AsA did not decrease MDA concentration in leaves. According to Smolik et al. [2013], higher concentration of proline

\section{REFERENCES}

AGAMI R.A. 2014. Applications of ascorbic acid or proline increase resistance to salt stress in barley seedlings. Biologia Plantarum, 58, 2: 341-347.

ASHRAF M., KARIM F., RASUL E. 2002. Interactive effects of gibberellic acid $\left(\mathrm{GA}_{3}\right)$ and salt stress on growth, ion accumulation and photosynthetic capacity of two spring and MDA in plant tissue may suggest that plants were affected by salt stress.

\section{CONCLUSIONS}

1. Application of AsA increased seed germination, shoot and root length, $\mathrm{Chl} a, \mathrm{Chl} b$ and Car content in 14-day-old tomato seedlings of cvs. Oxheart and Vilma.

2. The seedlings of cv. Oxheart were characterised by low tolerance to $\mathrm{NaCl}$ and $\mathrm{KCl}$ treatment at seedling stage.

3. The addition of AsA to the medium had no significant effect on plant growth $\mathrm{cv}$. Vilma under salinity stress conditions. Length of the roots constituted an exception, where plants treated with $\mathrm{NaCl}$ alone or $\mathrm{NaCl}$ with $\mathrm{AsA}$ developed roots longer by $48-73 \%$ compared to the control.

4. Salinity caused a significant reduction of $\mathrm{Chl} a, \mathrm{Chl} b$ and Car in leaves cv. Vilma, compared to the control. Tomato plants treated with $\mathrm{NaCl}$ and $\mathrm{AsA}$ had higher level of proline and MDA in leaves. wheat (Triticum aestivum L.) cultivars differing in salt tolerance. Plant Growth Regulators, 36, 1: 49-59.

ASLAN R., BOSTAN N., AMEN N., MARIA M., SAFDAR W. 2011. A critical review on halophytes: salt tolerant plants. Journal of Medicinal Plant Research, 5: 7108-7118. 
ARNON D.J., ALLEN M.B., WHATLEY F. 1956. Photosynteis by isolated chloroplast. Biochimica and Biophysica Acta, 20 : 449-461.

BATES L. S. 1973. Rapid determination of free proline for waterstress studies. Plant and Soil, 39: 205-207.

BYBORDI A. 2012. Effect of ascorbic acid and silicium on photosynthesis, antioxidant enzyme activity, and fatty acid contents in Canola exposure to salt stress. Journal of Integrative Agriculture, 11, 10: 1610-1620.

CUARTERO J., FERNANDEZ-MUÑOZ R. 1999. Tomato and salinity. Scientia Horticulturae, 78: 83-125.

CUARTERO J., BOLARIN M.C., ASINS M.J., MORENO V. 2006. Increasing salt tolerance in the tomato. Journal of Experimental Botany, 57,5: 1045-1058.

DEMIR Y., KOCAÇALIŞKAN I. 2002. Effect of $\mathrm{NaCl}$ and proline on bean seedlings cultured in vitro. Biologia Plantarum, 45 , 4: 597-599.

GOEL D., SINGH A.K., YADAV V., BABBAR S.B. 2010. Overexpression of osmotin gene confers tolerance to salt and drought stresses in transgenetic tomato (Solanum lycopersicum L.). Protoplasma, 245, 1-4: 133-141.

HENDRY G.A.F., GRIME J.P. 1993. Methods in comparative plant ecology. Marcel Dekker, New York, pp.282.

JONES R.A. 1986. High salt tolerance potential in Lycopersicon species during germination. Euphytica, 35: 575-582.

KHAN T.A., MAZID M., MOHAMMAD F. 2011. A review of ascorbic acid potentialities against oxidative stress induced in plants. Journal of Agrobiology, 28, 2: 97-111.

KRUPA-MAŁKIEWICZ M., FRANCZAK M., GRABIEC M., SMOLIK B., SMOLIK M. 2014. Genotypic differences between tomato cultivars differing in their response to salinity stress. Folia Pomeranae Universitatis Technologiae Stetinensis, 309, 29: 75-84.

LICHTENTHALER H.K., WELLBURN A.R. 1983. Determinations of total carotenoids and chlorophylls $a$ and $b$ of leaf extracts in different solvents. Biochemical Society Transactions, 11: 591-592.

PRICE A.H., HENDRY G.A.F. 1991. Ion-catalyzed oxygen radical formation and its possible contribution to drought damages in nine native grasses and three cereals. Plant Cell Environment, 14: 477-484.

RAHNAMA H., EBRAHIMZADEH H. 2004. The effect of $\mathrm{NaCl}$ on proline accumulation in potato seedlings and calli. Acta Physiologiae Plantarum, 26,3: 263-270.
RZEPKA-PLEVNEŠ D., KULPA D., SMOLIK M., GŁÓWKA M. 2007. Somaclonal variation in tomato $L$. pennelli and $L$. peruvianum f. glandulosum characterized in respect to salt tolerance. Journal of Food, Agriculture \& Environment, 5, 2: 194-201.

RZEPKA-PLEVNEŠ D., KRUPA-MAŁKIEWICZ M., TWARDOWSKA M., KUREK J., WYBORSKA K. 2008. Variability of rye varieties and breeding strains tested for tolerance to drought in in vitro cultures. Journal of Food, Agriculture \& Environment, 6, 2: 265-271.

SAEIDI-SAR S., ABBASPOUR H., AFSHARI H., YAGHOOBI S.R. 2013. Effects of ascorbic acid and gibberellin $\mathrm{GA}_{3}$ on alleviation of salt stress in common bean (Phaseolus vulgaris L.) seedlings. Acta Physiologiae Plantarum, 35: 667-677.

SAJID Z.A., AFTABLE F. 2009. Amelioration of salinity tolerance in Solanum tuberosum L. by exogenous applicatiob of ascorbic acid. In Vitro Cellular \& Developmental BiologyPlant, 45: 540-549.

SMIRNOFF N., WHEELER G.L. 2000. Ascorbic acid in plants: biosynthesis and function. CRC Crit. Rev. Plant Science, 19: 267-290.

SMOLIK M., KRAM P., KRUPA-MAŁKIEWICZ M., SMOLIK B., MALINOWSKA K. 2011. Response of tomato genotypes to sainity stress assessed at the seedlings stage. Electronic Journal of Polish Agricultural Universities, 14, 4: \#17.

SMOLIK B., MIŚKOWIEC A., REKOWSKA E., ZAKRZEWSKA H., ŚNIOSZEK M. 2013. The influence of particular biostimulators on some biochemical parameters in broccoli (Brassica oleracea L. var. Botrytis italica Plenck). Environmental Protection and Natural Resources, 24, 3: 2527.

SUDHAKAR C., LAKSHIM A., GIRIDARAKUMAR S. 2001. Changes in the antioxidant enzyme efficacy in two high yielding genotypes of mulberry (Morus alba L.) under $\mathrm{NaCl}$ salinity. Plant Science, 161: 613-619.

YAMADA M., MORISHITA H., URANO K., SHIOZAKI N., YAMAGUCHI-SHINOZAKI K., SHINOZAKI K., YOSHIBA Y. 2005. Effects of free proline accumulation in petunias under drought stress. Journal of Experimental Botany, 56, 417: 1975-1981. 